\title{
ACCESSORY RARE EARTH. STRONTIUM , BARIUM AND ZIRCONIUM MINERALS IN THE BENFONTEIN AND WESSELTON CALCITE KIMBERLITES.
}

\author{
Roger H. Mitchell.
}

\section{Department of Geology, Lakehead University, Thunder Bay, Ontario, Canàda P7B 5E1.}

Calcite kimberlites are rocks formed from highly differentiated kimberlite magma. As such they might be expected to possess an unusual mineralogy as a consequence of the concentration of incompatible elements in these residual magmas. To examine this possibility, calcite kimberlites from the Benfontein sills Dawson and Hawthorne 1973) and the Wesselton Water Tunnels sills (Mitchell 1984) were investigated by SEM/EDS techniques. The study demonstrated the ubiquitous presence of $\mathrm{REE}-, \mathrm{Sr}-$ and $\mathrm{Ca}-$ Ba-carbonates, Ba-titanates, kinoshitalite, primary $\mathrm{Ca}-$ zirconate, Nb-rutile and baddeleyite

\section{Carbonates}

Carbonate diapirs at Benfontein contain five distinct carbonates. The earliest carbonate to form was dolomite. This lines the margins of the diapir and forms euhedral crystals within the core of the structure. Dolomite is included in $\mathrm{Mn}$-bearing ankerite and both minerals are set in a matrix of calcite. Compositional variational, with the exception of $\mathrm{Mn}$ in ankerite (2-6 wt. $\mathrm{MnO})$, is relatively limited (figure 1). Ancylite occurs as euhedral crystals which appear to have crystallized contemporaneously with dolomite. They exhibit a wide range in composition (Table 1, figure 2) with respect to their sro (8-23 wt\%) and REE contents $\left(24-33\right.$ wt. $\left.\% \mathrm{Ce}_{2} \mathrm{O}_{3}\right) \cdot \mathrm{Ca}-\mathrm{Ba}$ carbonate (benstonite or barytocalcite ?) occurs as rounded-to-irregular exsolution patches in dolomite. Associated phases in the diapir include pyrite and strontiobarite. Sr-free REE-carbonates appear to be absent from the diapirs. A similar $\mathrm{Ca}-\mathrm{Ba}$ carbonate, also of exsolution origin occurs in calcite, in the Premier Mine calcite kimberlite.

The groundmass of the kimberlite hosting the diapirs consists primarily of calcite with rare dolomite, apatite, spinels, rutile, ilmenite and serpentine. Ancylite and Srpoor REE-carbonates are common as replacements of rutile and spinel, and as randomly orientated acicular crystals commonly intergrown with ilmenite laths. The sr-poor carbonates are of relatively constant composition (Table 1 , Figure 2) and are considered on the basis of their low CaO (5-6 wt\%) contents to be parisite-Ce.

\section{Hollandite}

Euhedral-to subhedral $\mathrm{Ba}-\mathrm{Fe}$-titanates are common in the calcite - apatite-rich groundmass of the Benfontein kimberlites and rare in the Wesselton sills. The titanates are $\mathrm{K}$-free, $\mathrm{Nb}$-bearing, $\mathrm{Fe}$-Ba-titanates (Table 2) belonging to the hollandite group of minerals. The titanates represent compositions between the end members $\mathrm{BaFe}_{2} \mathrm{Ti}_{6} \mathrm{O}_{16}$ and $\mathrm{BaFe}_{2} \mathrm{Ti}_{7} \mathrm{O}_{16}$. Their composition is not similar to priderites found in lamproites or Ba-titanates in group 2 kimberlites. Similar titanates are known from the Arbarastakh carbonatite complex.

potassian Kinoshitalite.

The groundmass of zirconolite-bearing Benfontein kimberlite contains poikilitic plates of potassian, kinoshitalite $(\mathrm{K}, \mathrm{Ba}) \mathrm{Mg}_{3} \mathrm{Al}_{2} \mathrm{Si}_{2} \mathrm{O}_{10}(\mathrm{OH})_{2}(\mathrm{Table} 2)$. This mineral 
has not previously been reported from kimberlites, although it is a common late stage mineral in both sodic and potassic alkaline volcanic rocks e.g. New South Wales leucitites, Bathurst Island nephelinites.

zirconolite/Zirkelite.

Zirconolite, accompanied by baddeleyite, has previously been reported from the Benfontein sills by Raber and Haggerty (1979), as a product of reactions between ilemnite, zircon and residual ca-rich fluids. In contrast zirconolite/zirkelite found during the course of the current study occurs as isolated 5-30 micron euhedral-tosubhedral single crystals scattered throughout the kimberlite groundmass. The mineral was evidently an early crystallizing phase and many of the crystals now exhibit irregular embayed margins indicative of subsequent resorption. In the Benfontein sills their is an antipathetic relationship between the presence of baddeleyite and zirconolite/zirkelite. In the Wesselton sill, baddeleyite is absent and zirconolite/zirkelite is the principal Zr-bearing phase, together with rare kimzeyitic garnet. Table 2 shows that the $\mathrm{Ca}$ zirconate found in the present work is much richer in $\mathrm{Zr}$ than typical zirconolites $\left(\mathrm{CaZrTi}_{2} \mathrm{O}_{7}\right)$, including the reaction variety described by Raber and Haggerty (1979). The composition is considered to be closer to that of zirkelite (CaTizr) ${ }_{3} \mathrm{O}_{5}$ than zirconolite.

\section{Nb-Rutile}

Niobian rutile is common as 10-50 micron euhedral groundmass crystals in the Benfontein sills. Commonly, the crystals are extensively replaced by magnetite, ankeritic carbonate, parisite and ancylite. Mantles of ilmenite are also commonly present. Rutile appears to have been a primary groundmass phase which crystallized contemporaneously with unevolved Cr-bearing spinels. The rutile contains $1.5-3$ wt $\% \mathrm{Nb}_{2} \mathrm{O}_{5}$ (Table 2).

\section{Fersmite}

Two euhedral grains of fersmite, $\mathrm{CaNb}_{2} \mathrm{O}_{6}$, enclosed by calcite were encountered in one sample from Benfontein. The crystals are of uniform composition and contain 69.5 wt.\% $\mathrm{Nb}_{2} \mathrm{O}_{5}, 16.2$ wt. $\% \mathrm{CaO}, 6.8$ wt. $\% \mathrm{Ce}_{2} \mathrm{O}_{3}, 3.5$ wt. $\% \mathrm{Fe}_{2} \mathrm{O}_{3}$, and 1.6 wt. $\%$ sro.

Rare earth and strontium rich carbonates have not previously been reported from group 1 kimberlites, although they are common in REE-rich group 2 kimberlites (e.g. bastnesite-Ce in the Frank Smith and Bellsbank occurrences, Mitchell unpub.data). Their presence in the Benfontein sills undoubtedly results from the concentration of REE and $\mathrm{Sr}$ in late stage carbonate-rich fluids. However, the absence of similar carbonates in the Wesselton and Premier calcite kimberlites suggests that the Benfontein magmas were of either of unusual composition or underwent extreme differentiation. The presence of REE carbonates does not imply any affinities with carbonatites, as these minerals are now known to form in a variety of late stage hydrocarbothermal parageneses in rocks ranging in composition from nepheline syenite to peralkaline granite.

Dawson,J.B. , Hawthorne, B.H. 1973. Magmatic sedimentation and carbonatitic differentiation in kimberlite sills at Benfontein, South Africa. J.Geol.Soc.London,129, 61-85. Mitchell,R.H. 1984. Mineralogy and origin of carbonate 
segregations in a composite kimberlite sill. N.Jahrb. Mineral. Abh.150,185-197.

Raber,E., Haggerty, S.E. 1979. Zircon-oxide reactions in diamond-bearing kimberlites. Proc. 2nd. Internat.

Kimberlite Conf.1,229-240.

Table 1. Ancylite, parisite and $\mathrm{Ca}-\mathrm{Ba}$ carbonate composition.

Wt. $\%$

$\mathrm{BaO}$

$\mathrm{CaO}$

Sro

$\mathrm{FeO}$

$\mathrm{La}_{2} \mathrm{O}_{3}$

$\mathrm{Ce}_{2} \mathrm{O}_{3}$

$\mathrm{Pr}_{2} \mathrm{O}_{3}$

$\mathrm{Na}_{2} \mathrm{O}_{3}$

\begin{tabular}{rrrrrrr}
1 & 2 & 3 & 4 & 5 & 6 & 7 \\
\hline- & - & - & - & - & 48.8 & 48.0 \\
4.0 & 2.5 & 4.0 & 5.1 & 4.0 & 19.2 & 20.0 \\
22.6 & 15.3 & 8.1 & 1.3 & 0.5 & 1.1 & - \\
- & - & - & 3.4 & 0.3 & - & 0.6 \\
10.5 & 15.9 & 9.7 & 16.6 & 12.9 & - & - \\
24.1 & 28.9 & 33.3 & 32.8 & 34.7 & - & - \\
2.2 & 1.4 & 4.3 & 3.4 & 4.4 & - & - \\
6.8 & 6.3 & 10.5 & 7.0 & 12.5 & - & - \\
- & - & - & 1.1 & 1.1 & - & - \\
$--0-0$ & 70.3 & 70.9 & 70.7 & 70.4 & 69.1 & 68.6 \\
\hline 70.2 & 70.5
\end{tabular}

1-3 Ancylite-Ce; 4-5 parisite-Ce; 6-7 Ca-Ba carbonate

Table 2. Kinoshitalite, hollandite and $\mathrm{Ca}$ zirconate composition

\begin{tabular}{|c|c|c|c|c|c|c|}
\hline Wt. $\%$ & 1 & 2 & 3 & 4 & 5 & 6 \\
\hline $\mathrm{SiO}_{2}$ & 24.2 & 24.8 & - & - & - & - \\
\hline $\mathrm{TiO}_{2}$ & 0.0 & 0.0 & 68.4 & 70.2 & 2.7 & 2.0 \\
\hline $\mathrm{ZrO}_{2}$ & - & - & - & - & 85.2 & 84.1 \\
\hline $\mathrm{Nb}_{2} \mathrm{O}_{5}$ & - & - & 2.8 & 1.0 & - & - \\
\hline $\mathrm{Al}_{2} \mathrm{O}_{3}$ & 21.0 & 19.2 & - & $\cdot$ & - & - \\
\hline $\mathrm{FeO}^{3}$ & 1.5 & 2.7 & 13.7 & 15.0 & 0.0 & 1.6 \\
\hline MgO & .22 .5 & 24.2 & 0.8 & 0.0 & - & - \\
\hline $\mathrm{CaO}$ & - & - & - & - & 11.3 & 10.4 \\
\hline $\mathrm{BaO}$ & 23.8 & 23.5 & 14.1 & 13.2 & - & - \\
\hline $\mathrm{K}_{2} \mathrm{O}$ & 2.2 & 2.5 & 0.0 & 0.0 & - & - \\
\hline & 95.2 & 96.9 & 99.8 & 99.4 & 99.2 & 98.1 \\
\hline
\end{tabular}
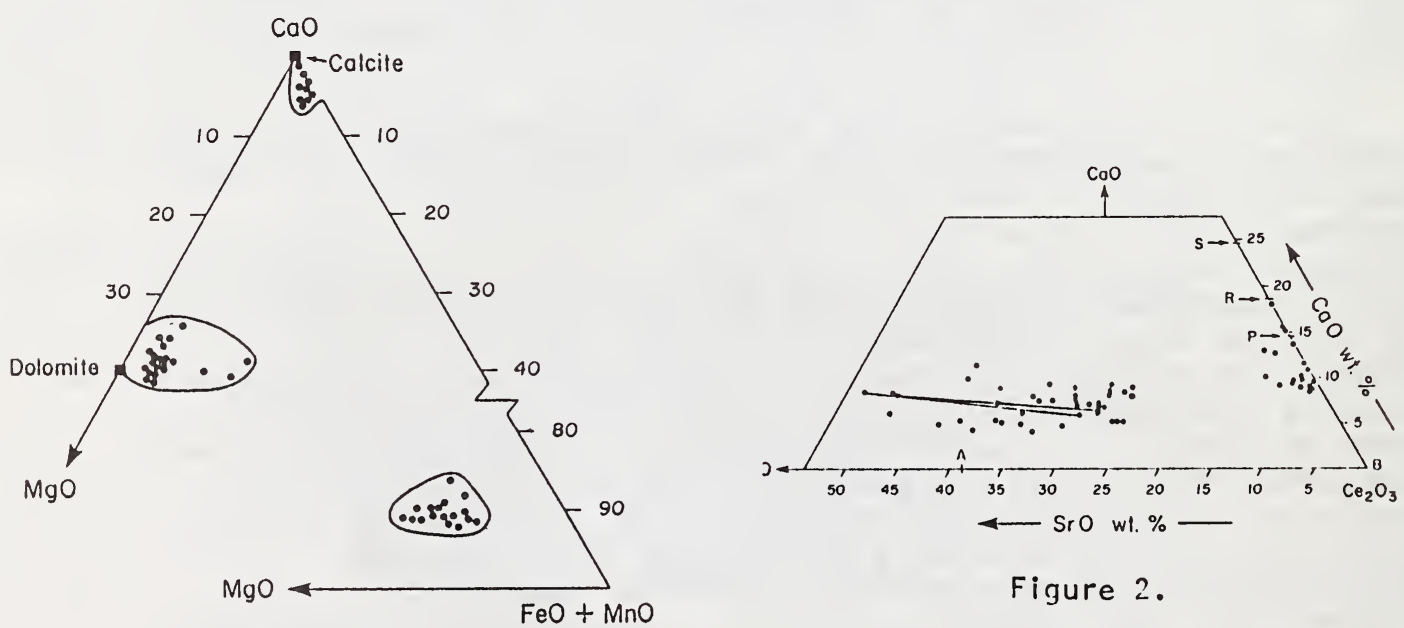

Figure 2.

Figure 1 